\title{
The Economic Implications of Belt and Road Initiative in the Development of Railway Transport Infrastructure in Africa: The Case of the Standard Gauge Railway in Kenya
}

\author{
Evaristus M. Irandu \\ Professor; Department of Geography \& Environmental Studies, University \\ of Nairobi, Hyslop Building, 3rd Floor, Main Campus, P.O. Box 30197-0o10o, \\ Nairobi, Kenya \\ eirandu@yahoo.com \\ Hesbon Hansen Owilla \\ Research Associate; Graduate School of Media \& Communications, \\ Aga Khan University, Nine (9) West Building, 7th Floor, Mkungu Close, \\ off Parklands Road, P.O. Box 30270-00100, GPO, Nairobi, Kenya \\ hesbonhansen@gmail.com
}

\begin{abstract}
The purpose of this paper is to examine the potential economic benefits the Standard Gauge Railway (SGR) project under Belt and Road Initiative (BRI) may bring to Kenya. This will contribute to the ongoing debate on whether Chinese investments on B RI infrastructure projects in Africa are mutually beneficial or not. The key issues discussed include the economic benefits of SGR in Kenya, the economic risks or challenges of SGR given the emergent issues of debt burden in Kenya and how China and Kenya would engage in the future to deepen Sino-Africa relations in BRI projects especially transport infrastructure. The paper relies on secondary information from available published literature on railway transport infrastructure in Africa with specific reference to SGR in Kenya. Information from key informants drawn from the Ministry of Transport and Infrastructure and the United States University based in Nairobi was used to enrich literature review. The main findings of the paper are: (1) SGR will lead to socio-economic development of the country (2) it will contribute revenue to the Government through the railway development levy levied on containerized transportation from the port of Mombasa, and (3) will boost trade and regional integration
\end{abstract}


through better rail connectivity. To make BRI projects more transparent, it is recommended that there is need for more stakeholder engagement in these projects. It is also recommended that the funding mechanism should be reviewed to make borrowing more affordable.

\section{Keywords}

Belt and Road Initiative - debt trap - infrastructure - market liberalization - Standard Gauge Railway

\section{$1 \quad$ Introduction}

The Belt and Road Initiative (BRI) launched by the Chinese President Xi Jinping in September 2013 is considered as a new global development model. This is so because within six years after its launch in 2013 , more than 15 o countries have signed cooperation documents with China. While a lot of studies have been carried out on the impacts of BRI in Asia and Europe, few exist in Africa. It is not clear from the existing scanty and fragmentary literature what the benefits and challenges of BRI projects are likely to be on the continent.

The purpose of this paper is to examine the potential economic benefits the SGR project under BRI may bring to Kenya. This will contribute to the ongoing debate on whether Chinese investments on BRI infrastructure projects in Africa are mutually beneficial or not. The key issues discussed include the economic benefits of SGR in Kenya, the economic risks or challenges of SGR given the emergent issues of debt burden in Kenya and how China and Kenya would engage in the future to deepen Sino-Africa relations in BRI projects especially transport infrastructure.

The paper relies on secondary information from available published literature on railway transport infrastructure in Africa with specific reference to SGR in Kenya. Information from key informants drawn from the Ministry of Transport and Infrastructure and the United States University based in Nairobi was used to enrich literature review.

\section{2 BRI as Growth Model for Africa}

As Dossou (2018) argues, the emergence of the Chinese BRI opened a new chapter in the history of relations between China and Africa. The BRI is designed to 


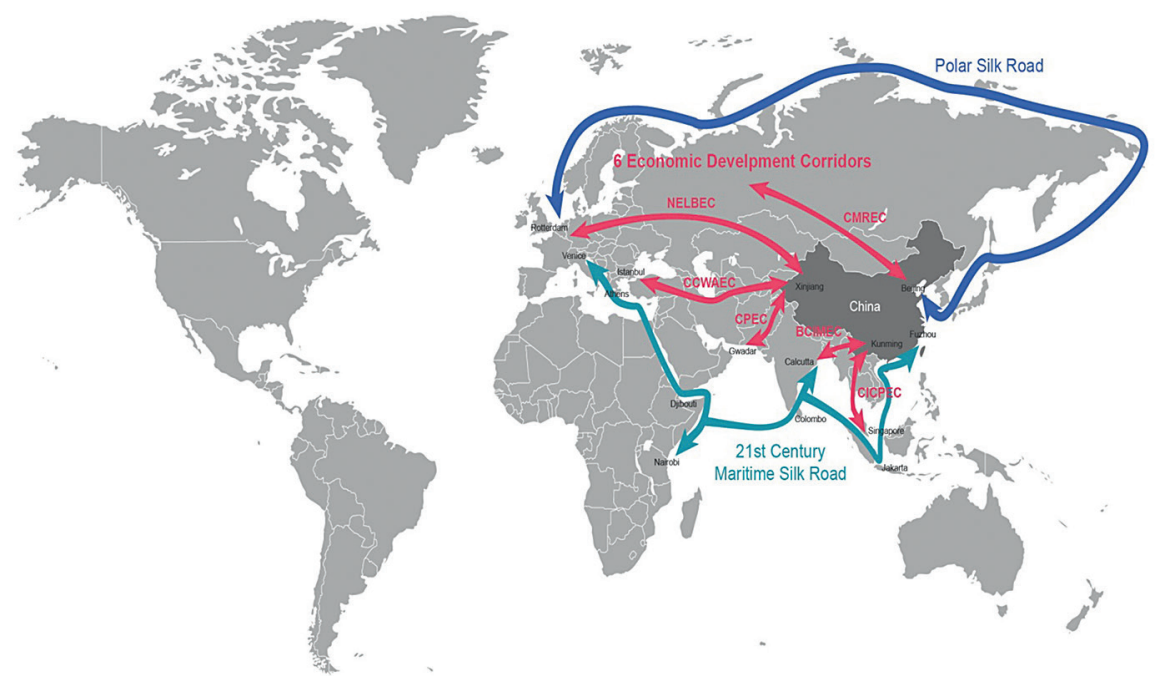

FIGURE 1 Map of the Belt and Road Initiative

SOURCE: https://www.beltroad-initiative.com/belt-and-road/

improve trade and infrastructure beyond China's borders in Asia and Europe. It also involves projects in Africa although as an afterthought (Ubi, 2019). BRI is lauded as the best growth model for Africa (Yakunin, 2019). This is represented by land corridors that connect China to Europe and Africa, through the New Silk Road Economic Belt. Another strategic component of this connectivity infrastructure and its vast spatial geography are the sea corridors, or the 21st century Maritime Silk Road, which links the South China Sea, the South Pacific Ocean, the Indian Ocean, the Persian Gulf, the Mediterranean Sea and the eastern coast of Africa (Fig. 1).

Africa could overcome some of its development challenges through building of synergies between Agenda 2063 and the BRI. China not only is Africa's largest trading partner but has also established a critical geopolitical presence across the continent. There is need to develop transport infrastructure to open up Africa for international and inter regional trade. The continent's transport infrastructure is poorly developed especially rail transport where colonial powers deliberately built railways of different gauges in their respective spheres of influence (Fig. 2).

The new Silk Road, a massive infrastructure initiative is not limited to Asia and Europe. The maritime extension connects Chinese ports with the coasts of Africa, and Chinese-sponsored new railways make the African hinterland more accessible too. However, many of Africa's exports to China comprise low value-added commodities, whereas African countries import relatively higher 


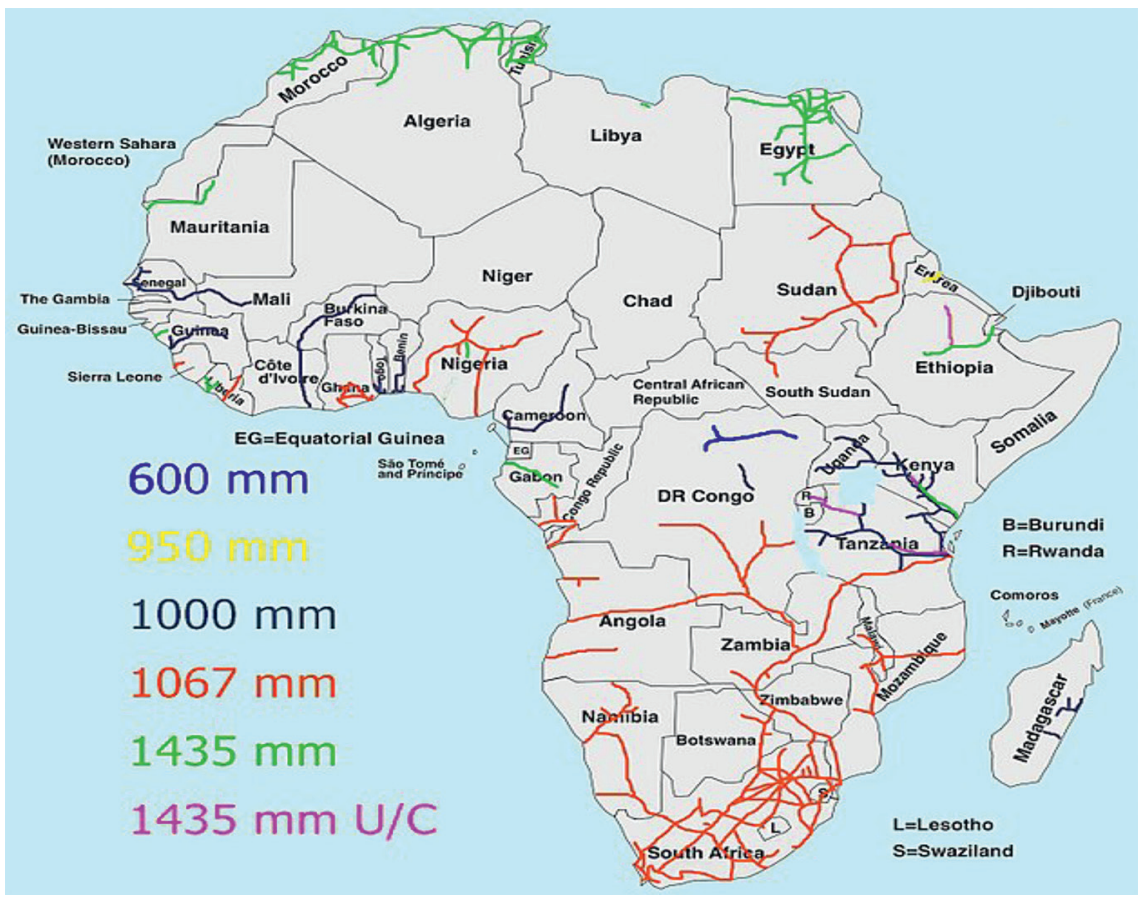

FIGURE 2 Map of African railways by gauge. U/C means "under construction" MODIFIED FROM MARCELO ET AL. (2019): 7

value-added and manufactured products from China, including capital and consumer goods.

The B RI aims at establishing Kenya as the new hub in Africa. What is important for Sub-Saharan African countries is how to take advantage of the strong BRI project focus on infrastructure. Much of the investment in these projects will come from Chinese state-owned enterprises with which African countries have had considerable negotiating experience and operational interaction (Tiberghien, 2017).

BRI offers opportunities that could support African Union's integration agenda or agenda 2063 .

These opportunities could build on the Forum on China Africa cooperation (FOCAC) process, in addressing Africa's infrastructure gaps, which currently impede integration. Trough BRI railway transport infrastructure projects, Africa's participation in regional and global value chains could be enhanced by opening up potential avenues for industrial development. 


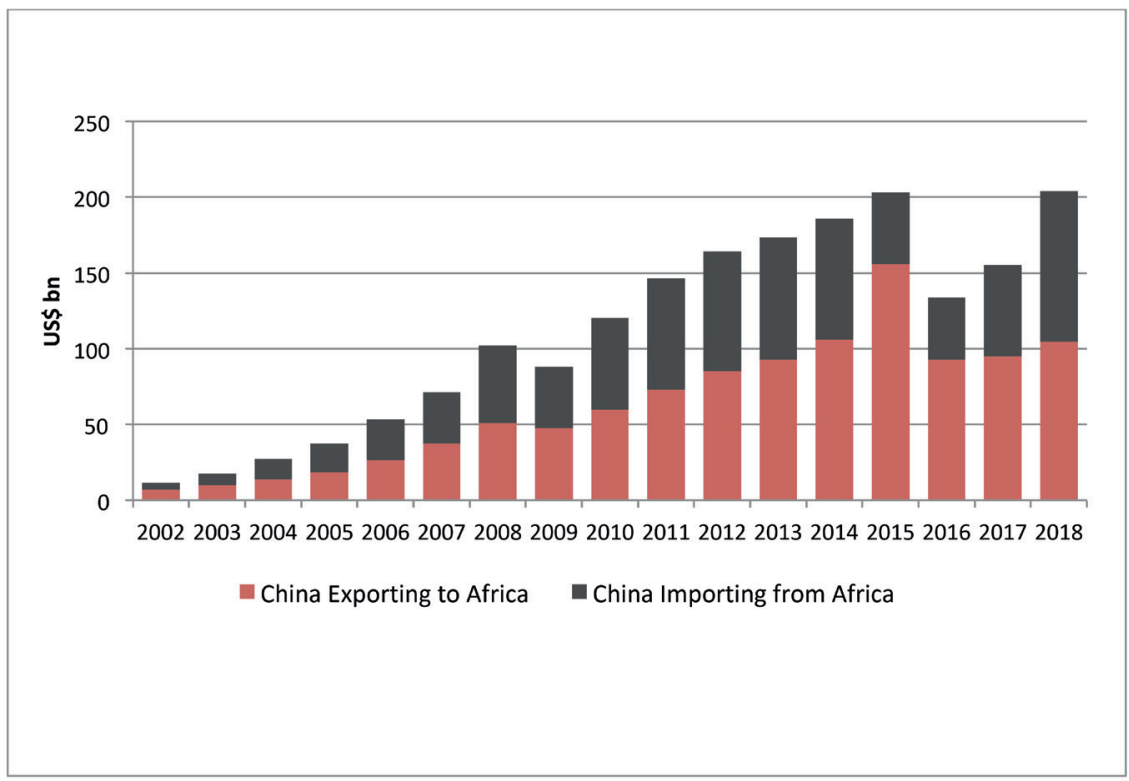

FIGURE 3 China-Africa trade SOURCE: CHINA AFRICA RESEARCH INSTITUTE, JOHN HOPKINS SCHOOL OF ADVANCED STUDIES. RETRIEVED FROM http://www.sais-cari.org/ data-china-africa-trade

An important contribution that China can make to the diversification of economic activity in Africa is the outsourcing and relocation of its labor-intensive industries as well as low-skilled jobs to Sub-Saharan African countries. This will assist with increasing their supply capacity and broadening their production bases while developing more capital-intensive, high-tech industries within China (Sun, 2014).

China's increasing influence in Africa has been predicated on its being the primary consumer of African commodities and a major source of development finance and investment. Besides, China has challenged Western spheres of influence in Africa. The prevailing view within Africa is that the Sino-African partnership is a more equal one (symmetrical) than Africa's relationship with the West (Fig. 3).

Africa's relationship with the West has been oft-tainted by a perception that the net flow of resources between the West and Africa remains largely in West's favour. This asymmetrical relationship is characterized by unequal terms of trade, debt servicing and economic policies which tend to promote the 
extraction of resources. Consequently, this has led to the marginalization of the vast majority of African people (Criekinge, 2009; Cohen, 2015). This is why the Chinese leadership has been cautious not to project any form of 'hegemonism' towards Africa. China has tempered its commercial engagement with emphasis on notions of mutual respect, sincerity, friendship and solidarity (Dou, 2016).

\section{$3 \quad$ Chinese Investment in Railway Transport Infrastructure Development in Africa}

'If you want to prosper, first build roads', says a Chinese proverb (Baidu, 2018). This proverb appears to hold true for Africa as well. Africa should construct many roads, railways and ports as huge infrastructure gaps remain stumbling blocks to growth, investment and economic diversification. An important area for China's engagement in Africa is infrastructure finance. Infrastructure deficit is a key factor hampering Africa's integration with the global economy and its economic growth, China's main infrastructure activities in Africa are in transport and energy (Fig. 4). Loans for transport projects comprise $42 \%$ of the total, and these are divided fairly evenly between road and rail. Energy accounts for $30 \%$ of China's loans on the continent (AfDB and ICA, 2017).

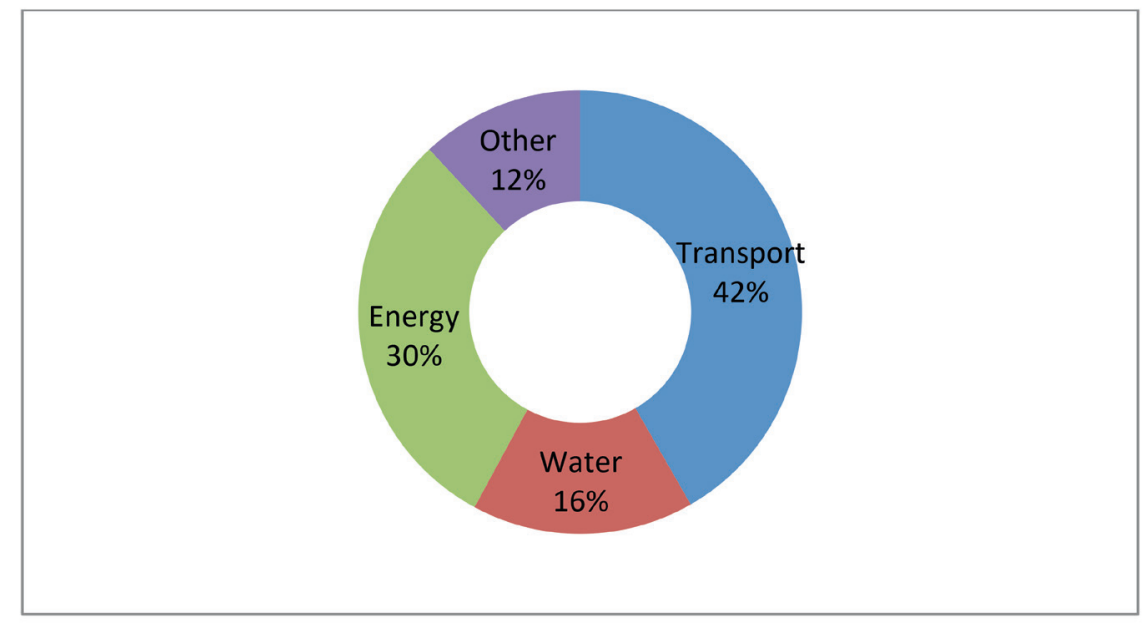

FIGURE 4 Total infrastructure financing in Africa by sector (2017) SOURCE: AFRICAN DEVELOPMENT BANK (AFDB) AND THE INFRASTRUCTURE CONSORTIUM FOR AFRICA (ICA) (2017). INFRASTRUCTURE FINANCING TRENDS IN AFRICA 
According to recent estimates by the African Development Bank (AfDB) (2018), Africa's minimum infrastructure needs is about US $\$ 130$ bn to US $\$ 170$ bn per annum. The continent needs to raise this huge amount of investment every year in order to sustain its economic growth and upgrade ageing and dilapidated railway and other transport infrastructure. Infrastructure investment is very important in enhancing business confidence, fosters innovation and productivity and lowers transaction costs, facilitates trade in goods and services and technology transfer (AfDB, 2018). The World Bank (2017) estimates that Sub-Saharan Africa's (SSA) gross domestic product (GDP) per capita growth would increase by 1.7 percentage points per annum if Africa were to close the infrastructure gap. This could also promote more inclusive growth and alleviation of poverty across the continent.

Kanai and Schindler (2019a) in their recent research on Africa's latest "infrastructure scramble" attempt to explain the logic and timing of the continent's infrastructure turn. They tend to associate the growing demand for infrastructure in Africa to the rise of a consumer middle class. However, Dodson (2017) considers the expansion of infrastructure as a "fix" for resolving spatial constraints that threaten conditions of capitalist production. Throughout Africa, governments appreciate the need for spatial planning and balanced regional development. At the same time, development banks are promoting spatial planning as an antidote to both market and state failure. From this perspective, Africa's infrastructure turn is linked to a growing number of national development plans that identify spatial disparities as the problem hindering development and balanced, well-connected spatial economies as the solution to underdevelopment (Kanai and Schindler, 2019a).

Today, there is growing dominance of China in Africa's infrastructure sector. Over the past two decades, China has helped to meet some of Africa's infrastructure financing needs and is now the single largest financier of African infrastructure, financing $20 \%$ of all the projects and constructing $75 \%$ of them (Madowo, 2018; Deloitte Africa, 2018). Most funded projects are in the road and rail transport, shipping and ports (52.8 per cent), followed by energy (17.6 per cent), real estate (14.3 per cent) and mining ( 7.7 per cent).

Part of the attractiveness of Chinese finance is that the loans are offered at subsidized and relatively low interest rates and with a maturity of 15 years or more. China Exim Bank is an export credit agency offering loans on a bilateral basis. It evaluates the level of concession taking into account the nature of the projects. The bank's competitive edge is that it allows countries that do not have enough financial guarantees to use their natural resources as collateral for infrastructure development. This funding model, known as the 'Angola 
model' has come in for serious criticism because using resources as collateral tends to reinforce the 'resource curse' of recipient economies (Brookings Institute, 2018).

While Chinese infrastructure investments on the continent have assisted a number of African countries to overcome their dependency on conditional foreign assistance and follow a non-interference clause, a frequent criticism is that such projects have produced little real benefit for local economies while increasing their debt burden. However, infrastructure investments, coupled with the establishment of Special Economic Zones (sEzs) in a number of African countries, could encourage positive spillovers and unlock economic potential in value-adding industries across the continent (Deloitte, 2019).

Dudzinski (2014) observed that although Chinese commercial practices have promoted stabilization of commodity prices and increased exports by the African countries, there is a downside. The high demand for primary resources by China resulted in reduced demand for manufactured goods from Africa. The huge demand for raw materials and energy means that Africa becomes a victim of deindustrialization and competition from cheap manufactured goods from China.

Railway transport infrastructure is the least developed in Africa (Sun, 2015), with very little additions to the systems developed in the colonial era. Except for the over 1,00o km long Tazara railway built by the Chinese in the 1970s, linking Tanzania with Zambia the lengths of the railway has remained unchanged throughout Africa. The Metre Gauge Railway (MGR) in Kenya built over a century ago, could only handle less than $10 \%$ of the Mombasa port's cargo capacity, leaving a heavy burden on road transport (Irandu, 2017e, 2018). This necessitated the modernization of railway transport in the country by constructing the SGR. This mega infrastructure project is a case of a strategic governmentto-government project with major implications for Kenya's economy.

The Eastern African coastal region is being looped into China's expanding sphere of commercial influence through connecting it to the 'Maritime Silk Route'. This is evidenced by the concentration of activity by Chinese financiers and builders in East Africa (Table 1). Although countries in East and also North Africa have been the largest recipients of Chinese investment to date, West and Southern African countries have also signed cooperation agreements under the BRI. Of strategic importance to East Africa is the construction of railway lines linking the hinterland of the region to coastal ports. Major projects include the Addis Ababa-Djibouti railway, and the Nairobi-Mombasa railway, which is part of the greater East Africa Railway Master plan (CPCS, 2009).

The Addis Ababa-Djibouti railway, estimated to have cost US $\$ 4.5$ bn, has cut the journey time over the $759 \mathrm{~km}$ route from three days by road to 12 hours 
by rail. The project eases logistical bottlenecks in the region, giving Ethiopia's manufactured goods greater access to global export markets. This railway line is considered as the first trans-boundary and longest electrified railway on the African continent'. This is one of BRI projects which has offered a lifeline to both Ethiopia and Djibouti (New China, 2018).

Chinese-financed infrastructure development is likely to make Djibouti the logistics hub for the East Africa region. In addition to the port, the Djibouti multipurpose free trade zone is financed by China (Chen, 2018). Chinese firms have also been active in planning and rehabilitating port infrastructure along the East African coastline. Chinese State-Owned Enterprises (soes) are financing and building an expansion of the port of Lamu in Kenya. The three additional berths are expected to cost US $\$ 500 \mathrm{~m}$ and are projected to increase the annual throughput to $23.9 \mathrm{~m}$ tonnes in the next decade (China Daily, 2017).

TABLE 1 Financed Belt and Road Projects in Africa

\begin{tabular}{lll}
\hline Ports & Country & $\begin{array}{l}\text { Investment type \& amount in } \\
\text { USD mill. }\end{array}$ \\
\hline $\begin{array}{ll}\text { Doraleh Multipurpose } \\
\text { Port }\end{array}$ & Djibouti & $\begin{array}{l}\text { US } \$ 294 \text { million concessional Exim } \\
\text { bank loan }\end{array}$ \\
$\begin{array}{l}\text { Damerjog Livestock } \\
\text { Port }\end{array}$ & Djibouti & $\begin{array}{l}\text { US } \$ 51 \text { million concessional Exim } \\
\text { bank loan }\end{array}$ \\
\hline
\end{tabular}

\section{Railways}

Addis-Djibouti SG R

Addis-Djibouti SGR

Mombasa-Nairobi SG R

Nairobi-Naivasha SGR

Industrial Zones

Multipurpose Free

Trade Zone
Ethiopia

Ethiopia

Kenya

Kenya

Djibouti
US\$ 2.49 billion commercial

Eximbank loan

US\$ 392 million Eximbank loan

US \$ 2 billion Eximbank commercial loan; US $\$ 1.6$ billion concessional loan

US\$ 1.5 billion loan

US\$ 150 million suppliers credit from China Merchants Group

SOURCE: CHEN (2018) 
Due to the deterioration of the metre gauge railroad and loss of significant cargo to road transport, a need arose to improve the rail corridor between Nairobi and the port of Mombasa to make it efficient and competitive (Irandu, 2017e, 2018). In May 2014, during his visit to Kenya, Chinese Premier Li Keqiang and Kenyan President Uluru Kenyatta signed a US $\$ 3.8$ billion contract to build the 472 km SGR linking the Port City of Mombasa with Nairobi, the Capital City of Kenya. The project involved building a standard gauge railway that would meet ultra-modern standards with high speed and high capacity for both passenger and freight transport. With average speeds of between $80-120 \mathrm{~km}$ per hour (Kph) for freight trains and between $120-160 \mathrm{~km}$ per hour $(\mathrm{kph})$ for passenger trains, the SGR has cut the round trip from Mombasa to Nairobi to about eight hours for freight and about four hours for passengers.

The China Export-Import (Exim) Bank provided 90\% of the US\$ 3.8 bn in financing phase 1 of the SGR from Mombasa to Nairobi. China Road and Bridge Corporation ( $\mathrm{CRBC}$ ) served as the contractor and built the railway line according to the Chinese railway design standards. The SGR is the largest project of its kind since Kenya's independence. Phase 1 of the SGR was opened. Construction began in October 2013 on Phase 1 and the new SGR was inaugurated on May 31, 2017 closing a 110-year chapter of reliance on colonial infrastructure (Wissenbach et al., 2017). Negotiations are on-going with financiers for funding SGR extensions from Nairobi to Kisumu and then to Malaba. When complete the SGR will connect cities in Kenya with those in Uganda, Rwanda, South Sudan and Ethiopia as part of a broader strategy for regional integration in East Africa. The mega infrastructure project is particularly important because it was Kenya's own idea, unlike the Kenya-Uganda Railway built by the British during the 19th century colonial rule. The SGR aims to open up East and Central Africa to international trade. But, the investment has sparked controversy concerning its economic viability, opaque contracting practices, financing arrangements, and community and labor issues (Mungai, 2016).

The Kenyan Standard Gauge Railway (SGR) Northern Corridor has three main routes which are: the Mombasa to Nairobi (Phase I) which is $485 \mathrm{~km}$; Nairobi to Naivasha which is $120 \mathrm{~km}$ and then Naivasha to Kisumu and Malaba which is $369 \mathrm{~km}$ (Fig. 5). The Lamu Port, South Sudan and Ethiopia Transport (LAPSSET) Corridor is likely to play a key role in Kenya's national development and spatial planning. According to the Kenyan government, LAPSSET is the backbone for opening up Northern Kenya and integrating it into the national economy (GoK, 2012: 6; Schindler et al., 2018). Through the $2000 \mathrm{~km}$ long transport corridor, Kenya aims to create a "seamless" and "connected" Africa 
(LCDA, 2016). The government intends to use LAPSSET to transform northern Kenya into a nationally and transnationally networked functional region that is linked to global supply chains (Kanai and Schindler, 2019b).

The LAPSSET project components consist of development of Lamu port, SGR line, highway, crude oil pipeline and product pipeline, oil refinery, resort cities and airport. Some of these elements are in progress. For instance, the Lamu Port construction was launched on 2nd March 2012 and is still ongoing, whereas an airport in Isiolo is already complete. The SGR and pipeline are planned to link the Port of Mombasa to the oil fields of South Sudan and Uganda (LCDA, 2016).

The LAPSSET project is intended to provide seamless transport between the Eastern African Countries of Kenya, Ethiopia and South Sudan, connecting an estimated population of 160 million people across these three countries. Further, the corridor is part of the larger land bridge intended to connect the East African coast from Lamu Port to the west coast of Africa at Douala Port, Cameroon. When complete, the LAPSSET project will realize the African

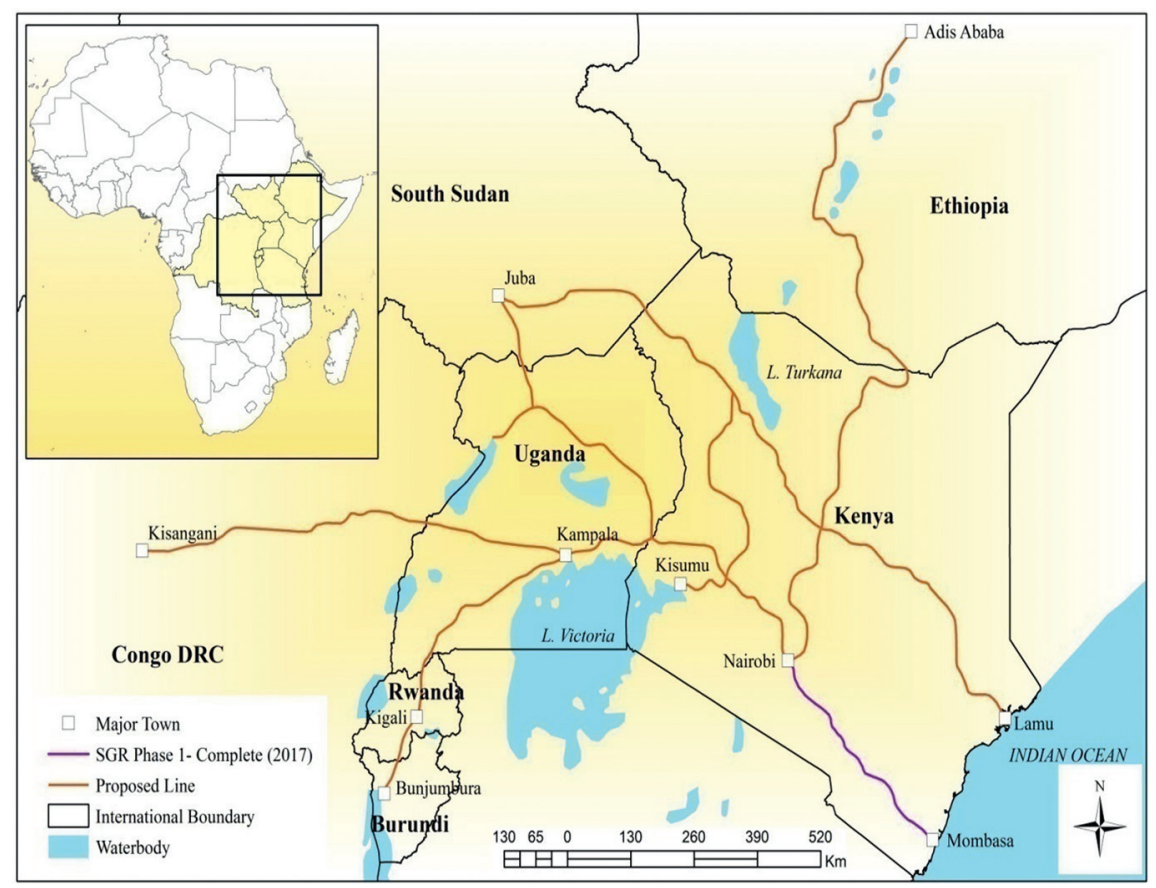

FIGURE 5 The proposed SGR lines in East Africa SOURCE: KENYA RAILWAYS, ETHIOPIAN RAILWAY COMMISSION AND TRANSIT TRANSPORT COORDINATION AUTHORITY 
dream of the east-west link. This will be the first time two oceans, the Indian Ocean and Atlantic Oceans will be linked by railway in Africa (Irandu, 2018).

\section{Economic Implications of Investment in SGR}

\subsection{Economic Benefits of SGR}

The construction of the SGR has brought economic benefits to the local communities and the Kenyan economy as a whole. The SGR has positively impacted local economies by supporting local businesses and creating new business opportunities. The patronage of SGR workers to local businesses has increased demand for goods for daily consumption. Several banks opened new branches to provide services to the railway employees, some of whom are starting their own small businesses. This was observed in Voi Town in Tata-Taveta County (Wissenbach and Wang, 2017). The areas around the SGR stations, along the routes, or towns where the trains stop are set for increased economic activity. This includes sprouting markets, hotels and an increase in transport and trade. When business people are assured of timely target markets for their produce, processing plants are bound to naturally sprout creating even more jobs (Kenya News, 2017).

The train stations could lead to the establishment of economic clusters and special economic zones (SEz), or industrial parks such as the one in Mombasa for logistics and another in Naivasha for manufacturing industries (Kenya News, 2017; Wissenbach and Wang, 2017). These special economic zones or industrial parks when fully established will offer employment opportunities to the local communities and promote industrial development. The Industrial Parks model which has succeeded in China is expected to spur industrialization in six countries in eastern Africa. Manufacturers will, be able to reduce the cost of sourcing inputs, lowering the overall cost of doing business and allowing them to remain competitive in both the domestic and regional market. The expeditious implementation of SGR is therefore a positive development for manufacturers and the broader business community (KRC, 2015; Kithinji, 2016).

According to the China Road and Bridges Corporation (2016), the SGR project had a total of 21,858 employees, including 2,00o Chinese management and technical personnel and 19,858 local employees. Among local employees, 4,69o were technical workers, 907 were management personnel and 14,261 were ordinary laborers. Kenyan workers worked as machine operators, truck drivers, surveyors, as other specialists, and as casual workers. In total, the SGR project has so far created over 38,00o jobs. The Standard Gauge Railway is estimated 
to create many indirect jobs including: 10,00o jobs in local industries and 3,000 jobs in service and hospitality industries. Other benefits as envisaged by Kenya Railways Corporation (2015) include training at least 15,000 people on skills that will enable them create self-employment (Waweru, 2016; Sanghi and Johnson, 2016).

SGR has improved efficiency of freight transport by shortening journey time between Mombasa and Nairobi and by reducing freight cost by about $79 \%$. According to Freight Africa (2018), the SGR trains each hauls about 52 wagons. The freight trains have a maximum capacity of 4,0oo tonnes, or 216 twenty foot equivalent units (TEUS), and the line has been designed to accommodate double-stack container trains (Freight Africa, 2018). This translates into job opportunities for the loaders and off loaders whether mechanized or manual and also provides opportunities for retail and wholesale distribution services for the end users. The passenger service trains referred to as the Madaraka Express are well designed to seat up to 1,200 passengers. There are two return SGR passenger trains per day between Mombasa and Nairobi. So far, about 2.7 million passengers and nearly 3.9 million tons of cargo have been transported since its launch in May (Freight Africa, 2018). Macharia Munene, a professor in the United States University (USIU) based in Nairobi appears to agree that SGR will save on time between Mombasa and Nairobi. He says "the speed of SG R in the transportation of goods and services will save on time and the cost of moving goods and services (people). The time saved would mean that people can be a lot more productive elsewhere and even in terms of movement of labour." (Professor Macharia Munene, Interview, 2020, December 8).

By providing a fast, efficient and reliable mode of transport, the SGR cargo trains have helped decongest the port of Mombasa by ensuring goods that arrive at the port are moved to the hinterlands without delays. The standard gauge railway has also reduced the cost of transporting cargo from Mombasa to the hinterlands. According to the Kenya Railways Corporation (KRC, 2015), it costs about $\mathrm{Sh}_{50,000}$ to transport a container through the SGR cargo trains compared to Sh 9o,ooo by road from Mombasa to Nairobi. The facility has enabled passengers to enjoy a faster and cheaper journey compared to eight-hour bus trips between Nairobi and Mombasa. The SGR has also led to reduction in the wear and tear on highways thereby reducing roads maintenance cost. The number of heavy trucks on the road has drastically reduced. This is expected to reduce the number of accidents; hence making the roads safer for human traffic (Irandu, 2017; Githaiga and Wang, 2019).

The Standard Gauge Railway passes through some land suitable for agricultural development. This is likely to create opportunities for agricultural production for towns along the SGR. Since different areas have their own potential, 
mostly agricultural, with frequent train transport, the products could be sent to further areas and oversea through Mombasa port. In this way, the farmers could have better earnings and encourage more business activities. In this way, there will be more job opportunities for these areas as well. The SGR may also promote tourism development especially in Tsavo East and Tsavo West National Parks. The railroad will bring the tourists from the coastal areas and upcountry areas as well (Irandu, 2018).

Mr. John Kimani, the Chief Economist in the State Department of Infrastructure in the Ministry of Transport and Infrastructure in Kenya observed that 'the SGR will promote and boost intra-Africa trade and investments thereby boosting regional integration through better rail connectivity. Additional trade and investment opportunities will lead to enhanced employment opportunities and livelihoods for the people in the EAC region' (Kimani, Interview, 2020, August 14). Therefore, the East African countries, especially the land locked countries stand to reap huge revenues from the SGR introduction. The SGR commencement of freight services for East Africa would cut costs and delays for businesses. Designed with an axle load of 25 tonnes, the SGR line is forecast to carry around 22 million tonnes of freight per year. The introductory offer for transport of a 20 foot container is about US $\$ 500$, and US\$ 700 for a 40 -foot container for a minimal chargeable distance of $300 \mathrm{~km}$. Professor Macharia Munene opines that within the BRI network, the corridor from the Port of Lamu to Duala in Cameroon is likely to be richer given that SGR and BRI will spur economic activities along this corridor. This is likely to have a spill over benefit to the countries along this corridor.

\subsection{Economic Problems Associated with the SGR}

However, the SGR is the most scrutinized project in Kenya and has not been without controversies typical of accusations against other Chinese mega-projects in the rest of Africa. Some of these controversies include the SGR's economic viability, cost, debt sustainability, corruption, opaque contracting and financing arrangements (Wissenbach and Wang, 2017). The rapid expansion in infrastructure credit that the BRI offers also brings significant risks. Many of the large infrastructure projects are supported through debt-based finance, raising questions over African economies' rising debt levels and its sustainability. The tax payer will now dig deeper in the pocket to ensure that the SGR remains operational. This is because the SGR operation between Nairobi to Mombasa costs KeS 1 billion (US $\$ 10$ million) to run every month. This makes the SGR one of the most expensive infrastructure projects in the country. Besides, in the first year of its operation, the SGR incurred a loss of about KES 10 billion (US\$100 million) (The Standard, 2018). 
The SGR project has bred tensions over the impact of construction on local community's livelihoods. In particular, there has been tension within local communities concerning employment opportunities. In some cases, the local communities demanded that their people be the only ones employed since the project passed in their area. Disputes over wages, land compensation, supply contracts and environmental impacts, have also been sources of disagreement within and between the local communities, the local authorities, and the Chinese contractors. Tensions developed over land ownership, and especially compensation payments, which galvanized locals, pitting them against both local authorities and Chinese contractors.

The impact of SGR on the trucker's economy is unclear. With the construction of SGR, some businesses have lost some customers. Cargo trucks and long-distance buses have lost some of their businesses with the flagging off of the SGR (Ogollah et al., 2019). If the proposal to convey all upcountry cargo through SGR is implemented, the implications to the Port City of Mombasa's GDP and employment sustainability will be serious. The Mombasa County is likely to lose about Kshs 33.3 billion (US $\$ 333$ million in income and 8.111 jobs (Ogolla et al., 2019). Close to 4,00o trucks ply the roads transporting various goods in and out of the East Africa region. The SGR is expected to decongest our roads and perhaps transport cargo cheaply. However, truck drivers numbering about 8,ooo, and informal businesses selling spare parts, repairing and maintaining trucks will be negatively impacted (Business Daily, 2017).

According to Mr. Kimani increased competition from other regional ports (e.g., Dare salam) may lead to reduced revenues to the Kenya Ports Authority (KPA). This may lead to inability to service and repay the SGR loans thereby increasing the level of indebtedness for Kenya (Kimani, Interview, 2020, August 8). Inability to pay by Kenya may also lead to lower debt ranking by donor agencies, thereby worsening Kenya's credit ranking at the international level. Ultimately, this will lead to a devaluation of the Kenyan shilling. A devalued currency will lead to increased borrowing costs and further exacerbate Kenya's debt crisis.

\subsection{Role of $s G R$ in Deepening Sino-Africa Relations}

With the construction of SGR Phase 1 from Mombasa to Nairobi, a new era of China-Kenya cooperation began in earnest. This is because Kenya serves as a gateway to Eat and Central Africa. The SGR is intended to open up a fastgrowing and progressively integrating region to Chinese and international trade and investment (Irandu, 2018).

Infrastructure development is one of the most important components of China-Africa cooperation under the Belt and Road Initiative (BRI). Through 
the BRI, movement of passengers and cargo has been enhanced. The Initiative not only aims to boost industrialization in Africa but also to build a community of shared future. In Africa, the East African countries lag significantly behind because of the lack of adequate and reliable transport. The recent Standard gauge railway project development comes as a unifying factor not just for Kenya but for the entire East Africa region. The SGR is considered as a tool for promoting harmony by strengthening interdependence in East Africa and minimizing conflicts (United Nations Economic and Social Council, 2009; Irandu, 2018). In line with Kenya's vision 2030, the SGR infrastructure is among the flagship mega projects in the region that focuses on reinforcing the regional framework for infrastructure and economic development. According to Professor Macharia Munene, the construction of SGR and other BRI projects is likely to deepen the Sino-Africa relations. He says "the Chinese people are always on site and not seated somewhere in Beijing or enjoying first class trips.... These arrangements build a relationship of trust, helps in quick attention to problematic issues and cuts down on cost considerably." (Professor Macharia Munene, Interview, 2020, August 12).

However, the "Belt and Road Initiative" (BRI) continues to draw both praise and criticism from "Sinophiles" and "Sino skeptics". Some hold the view that BRI aims at sharing the "Chinese Dream" of prosperity with other countries. Sinophiles argue that BRI heralds China's "ascendancy in the global arena" through the provision of public goods in the form of capital and technical services to other countries (Wang, 2016; Yu, 2016). Sino skeptics argue that China's BRI is a "neo-imperial project," (Griffiths, 2017; Phillips, 2017). Other critics observe that the Belt and Road Initiative is likely to lead to a "debt trap" especially for developing countries due to the usurious rates that China aims to impose on BRI member states (Chellaney, 2017). Xiang, a correspondent of Xinhua News Agency based in Nairobi observed that debt trap diplomacy has been a 'big buy for those with Cold War mindset, demonizing China's loans as creating economic dependency on Beijing.' He went on to argue that facts show that the BRI is helping lift countries out of a "trap of no development" rather than duping them into a "debt trap"' (Xiang, 2019). Some scholars cite the case of Sri Lanka in agreeing to a "debt for equity" swap with China due to her inability to pay for the loans used for the development of the Hambantota Port (Cardenas, 2017).

Sino-skeptics argue that Chinese loans in Africa are a strategy by the "neo colonialist" to extract concessions on assets. However, this is fallacious (Ubi, 2019). China's involvement with African nations under BRI extends beyond infrastructure. It is an experiment with China's development model, which 
having produced prosperity at home, can be replicated in Africa. This model has found favor in some East African nations, which have embraced some of its aspects through Chinese engagement in the region (http://en.people.cn/ n3/2019/0708/c9000o-959540o.html).

BRI can have positive net benefits for African countries, but much will depend on whether the China-Africa relationship can be placed on more equal footing. First and foremost BRI is a Chinese 'geopolitical project' designed to advance China's grand strategy. The challenge for Africa is in establishing where its interests converge with China's, where they diverge, and how areas of convergence can enhance China-Africa 'win-win strategy'. China should assist African countries to move away from their global position as a 'commoditized periphery'. It is imperative for African countries to work with China bilaterally, regionally and continentally in order to establish where the entry points might be to access BRI funding.

Taylor (2011) also noted that while China has an Africa policy regarding trade and investments, African countries and the AU do not have a China policy. The non-existence of Sino-African trade policies regarding investments in Africa weakens the bargaining power of Africa in its engagement with China. Absence of a clear-cut policy on the commercial relations between Africa and China means that predatory African elites may take advantage to advance their selfish needs.

\section{Research Gaps in Afro-China Engagement}

From the foregoing discussion, it is apparent that a lacuna exists in certain aspects of the Afro-China engagement. In order to have a more meaningful engagement resulting in 'win-win' situation in the future, there is need for interdisciplinary research in the following key aspects.

\subsection{Impacts of Mega BRI Infrastructure Projects in Africa}

It is important to assess over a long period of time (15-20 years) the economic, social, political, ecological and security risks of the BRI projects in Africa. It would make a lot of sense to evaluate the impacts of the SGR in Kenya over such a period of time. It is contended here that the Mombasa-Nairobi SGR was completed about two years ago. This is too short a time to authoritatively draw conclusions about its economic benefits or its ecological impacts in the areas it passes. We would be able to gauge the effect of the SGR in the breeding, migratory and feeding habits of wildlife over a long period of time. 


\subsection{Incentives and Policy Environment Necessary for Making SGR Competitive in Kenya}

In order for SGR to be competitive, it needs to come up with a viable revenue model. SGR needs to offer attractive packages to its customers which road transport operators do not offer. This would make SGR more attractive and may be capture a significant proportion of cargo from the road transport. An interdisciplinary research approach would help in establishing the best way(s) to raise sufficient revenue for the SGR.

Role of Industrial Parks in Industrializing Africa

While it is appreciated that industrial parks may stimulate industrial development, it is not clear how this may happen through BRI. There is need to carry out interdisciplinary research to establish the type of industries Africa needs to drive its economy. It should be born in mind that Africa is a labour surplus continent and labour intensive industrialization would offer more opportunities for job creation.

\section{Appropriate Resettlement Model and Compensation for Land Owners}

The cost of constructing the Mombasa-Nairobi SGR might have been increases by compensation to the land owners in the areas the railway passes. Many land owners were given cash payments as compensation for the land taken up by the SGR. Some complained later that their land was undervalued by the National Lands Commission while others squandered their cash thereby becoming impoverished. One wonders whether a cash payment policy s suitable for poor rural communities. Therefore, a more appropriate resettlement and land compensation policy needs to be formulated. An interdisciplinary research would inform the policy makers in coming up with a policy.

\section{Public Private Sector Partnerships in BRI Projects}

At the moment, there is a lot of competition for cargo between the SGR and the private truck operators. The truck operators have held demonstrations against 
the SGR monopoly in Mombasa. This paper advances the thesis that there is enough business for the SGR and truck operators. There are areas where the SGR has comparative advantage and areas where private sector has comparative advantage. The question then arises: In which BRI projects would public sector and private sector collaborate? What is required is a policy framework to guide the Public-private sector partnership (PPP). This fertile ground for interdisciplinary research.

\section{Conclusion and Policy Recommendations}

In conclusion, it has been established that a huge infrastructure gap exists in Africa and that BRI investments fill the gap. The Standard Gauge Railway (SGR) in Kenya is one of the mega infrastructure projects financed by China in East Africa. The modern railroad has contributed to the socio-economic development of Kenya and in the long term, is likely to spur economic growth and promote regional trade within the East African Community (EAC). The LAPSSET Corridor will provide a vital link between East Africa and West Africa, thereby opening up a huge area for trade and investments.

However, to maximize these benefits and to avoid pitfalls of dependency, it is recommended that African countries should take a common position that serves their interests. This is lacking at the moment. The funding mechanism should also be reviewed. There should be a shift from commercial funding of BRI projects to more concessionary funding at lower interest rates and longer repayment periods. This will enable African countries to borrow to finance BRI infrastructure projects at affordable costs. The funding of BRI infrastructure should also not be guaranteed through national assets such as ports or rail in case of default but should be guaranteed through Government to Government funding.

At the national level, Kenya should formulate policies that can enhance potential gains and limit negative effects from BRI projects. BRI projects appear lop-sided and may not necessarily serve national interests. This calls for proactive engagement from the Kenyan side to ensure win-win cooperation. All Chinese companies wishing to invest on any BRI project in Kenya should comply with national laws and regulations. The government should ensure adequate stakeholder engagement in the award of BRI contracts. Kenya should also diversify her trading partners so that any downturn in the growth of the Chinese economy may not impede economic growth of the country. 


\section{References}

African Development Bank. (2018). African Economic Outlook. Retrieved from www .afdb.org/en/knowledge/publications/african-economicoutlook/.

African Development Bank (AfDB) and the Infrastructure Consortium for Africa (ICA). (2017). Infrastructure financing Trends in Africa.

Africa Research Initiative (CARI). (2018). Our Data-Chinese Loans to Africa. Retrieved from http://www.sais-cari.org/data-chinese-loans-and-aid-to-africa.

Baidu, H. (2018). Want to prosper, first build roads. Retrieved from https://zhidao .baidu.com/ques-tion/559383047.html.

Belt Road Initiative (BRI). (2019). Offers Development and NOT Debt Trap. Retrieved from http://en.people.cn/n3/2019/o708/c9oooo-959540o.html.

Belt and Road Initiative. (2019). Belt and Road Initiative. Retrieved from https://www .beltroad-initiative.com/belt-and-road/.

Blumenfeld, M., Wemakor, W., Azzouz, L., \& Roberts, C. (2019). Developing a new technical strategy for rail infrastructure in low-income countries in Sub-Saharan Africa and South Asia. Sustainability, n(16), 4319. doi:10.339o/su1164319.

Brookings Institute. (2018). China's Aid to Africa: Monster or Messiah. Retrieved from www.brookings.edu/opinions/chinas-aid-to-africa-monster-or-messiah.

Business Daily. (2017, June 7). New SGR train service attracts foreign tourists. Business Daily, Retrieved from https://www.businessdailyafrica.com/news/SGR-to-boost -oastal-region-tourism/539 546-3959172-fjlvgyz/index.html.

Business Daily. (2017). Are we building pro-poor infrastructure? Retrieved from https:// anzetsewere.wordpress.com/2017/11/20/are-we-building-pro-poor-infrastructure/.

Cardenas, K. (2017). Duterte's China deals, dissected. ABS-CBN News. Retrieved from http://news.abs-cbn.com/.

Chellaney, B. (2017). China's debt-trap diplomacy. Project Syndicate. Retrieved from https://www.project-syndicate.org/commentary/china-one-belt-one-road-loans -debt-by-brahma-chellaney-2017-o1?barrier=accesspaylog, retrieved.

Chen, L. (2017). Private companies play key role in Belt and Road Initiative. China Daily. Retrieved from http://www.chinadaily.com.cn/world/2017-03/22/content _2864300o.htm retrieved.

Chen, Y. (2016). A Comparative Analysis: The Sustainable Development Impact of Two Wind Farms in Ethiopia. Working Paper No. 2016/7, Washington, DC: China Africa Research Initiative, November 2016.

Chen, Y. (2018). Silk Road to the Sahel: African ambitions in China's Belt and Road Initiative. China-Africa Research Institute, John Hopkins School of Advanced International Studies. Washington, D.C. China. Retrieved from https://mronline .org/wp-content/uploads/2018/10/56e44-yunnanbeltandroad-finalversion.pdf. 
China Daily (2019). Investment spurs BRI countries' growth. China Daily, Retrieved from http://www.chinadaily.com.cn/a/2019o4/23/WS5cbe4b9aa310484226ob7ao7 .html.

Cohen, S. B. (2015). Geopolitics: The Geography of International Relations. Rowman \& Littlefield.

CPCs. (2009). East African Railways Master Plan Study Final Report. East African Community, Arusha. Tanzania.

Criekinge, T. (2009). Power Asymmetry between the European Union and Africa? A case study of the EU's relations with Ghana and Senegal. PhD Thesis, London School pf Economics and Political Science.

Deloitte Africa. (2018). Africa Construction Trends. Retrieved from www2.deloitte .com/za/en/pages/energy-and-resources/articles/africa-construction-trends -report.html.

Dodson, J. (2017). The global infrastructure turn and urban practice. Urban Policy and Research, 35(1), 87-92.

Dou, D. (2016). Can China Eradicate Poverty? East Asia Forum, 20 July. Retrieved from http://www.eastasiaforum.org/2016/o7/30/can-china-eradicate-poverty/.

Doussou, T. A. M. (2018). The Impact of China's One Belt One Road Initiative in Africa. Evidence from Kenya. South Western University of Financial Economics in China. Retrieved from https://MPRA.Ub.uni_munchen.de/9046o/.

Dudzinski, J. (2014). Remarks on Export of Developing Countries of Asia, Africa and Latin America in the 21st Century. In B. Drelich-Skulska, A. H.Jankowiak \& S. Mazurek (Eds.), Redefinition of the Role of Asia-Pacific Region in the Global Economy (pp. 164-175). Wroclaw University of Economics. doi:10.15611/pn.2014.370.12.

Enns, C., \& Bersaglio (2019). On the Coloniality of "New" Mega Infrastructure Projects in East Africa. Antipode, 52(1), 101-123. doi: 10.1111/anti.12582.

Freight Africa. (2018, January 3). Mombasa - Nairobi standard gauge freight service launched. Railway Gazette.

Githaiga, N. M., \& Wang, B. (2019). Belt and Road Initiative in Africa: The Impact of Standard Gauge Railway in Kenya. China Report, 55(3), 219-240.

GoK. (2012). National Spatial Plan 2015-2045. Ministry of Lands and Physical Planning, Government of Kenya.

Griffiths, J. (2017). Just what is this One Belt, One Road thing anyway? CNN. Retrieved from http://edition.cnn.com/2017/05/11/asia/china-one-belt-one-road-explainer/ index.html.

Irandu, E. M. (2017e). A review of the impact of the Standard Gauge Railway (sGR) on Kenya's national development. World Transport Policy and Practice, 23(2), 22-37. 
Irandu, E. M. (2018). The China-Africa Infrastructure Cooperation. The Case of the Standard Gauge Railway, Final Paper for the African Economic Research Consortium (AERC), October, 2018. Nairobi.

Kanai, J, M., \& Schindler, S. (2019a). Peri-urban promises of connectivity: Linking project-led polycentrism to the infrastructure scramble. Environment and Planning A: Economy and Space 51(2), 302-322.

Kimani, J. (2020, August 14). Chief Economist. мот. Nairobi.

Kithinji, E. (2016). The importance of Standard Gauge Railway (SGR) Project to the East African Region. International Journal of Current Business and Social Sciences, $1(5), 15^{-32 .}$

Lapsset Corridor Development Authority. (2016). Brief on Lapsset Corridor. Retrieved from http://vision203o.go.ke/inc/uploads/2018/o5/LAPSSET-Project-Report-July -2016.pdf.

Lapsset Corridor Development Authority (LCDA). (2017). "Strategic Environmental Assessment Study in the Master Plan for the LAPSSET Corridor Infrastructure Development Project (LCIDP)-Draft Report." LAPssET Corridor Development Authority, Government of Kenya.

Macharia Munene. Professor. (2020, August 12). United States International University (USIU), Nairobi.

Madowo, L. (2018). Should Africa be wary of Chinese debt? в вC, Retrieved from www .bbc.com/news/world-africa-45368o92.

Mombasa-Nairobi Standard Gauge Railway Project. (n.d.). Retrieved from http:// www.railwaytechnologycom/projects/mombasa-nairobi-standard-gauge-railway -project/.

Mungai, R. (2016). Is China railroading Kenya into debt? Retrieved from http://www .scmp.com/week-asia/geopolitics/article/2026152/china-railroading-kenya-debt.

Mwiti, L. (2018, July 18). SG R makes Sh1o billion loss in first year. The Standard. Retrieved from https://www.standardmedia.co.ke/article/2001288487/sgr-.

New China. (2018). Chinese-built Ethiopia-Djibouti railway begins commercial operations. Retrieved from http://www.xinhuanet.com/english/newchina/index.htm.

Ngengi, A. W. (2018). Chinese investments in Africa and the politics of unsustainability: A case study of the Kenya's standard. Global Journal of Politics and Law Research, $6(7), 1-4$.

Ogollah, K., Rucha, K., Aroni, J., \& Gichiri N. (2019). Assessment report of the socio-economic impact of the operationalization of the Mombasa-Nairobi Standard Gauge Railway on Port City Mombasa. County Government of Mombasa. Retrieved from http://en.people.cn/n3/2019/o708/c9oooo-959540o.html. 
Phillips, T. (2017). The $\$ 900$ bn question: What is the Belt and Road Initiative? The Guardian. Retrieved from https://www.theguardian.com/world/2017/may/12/the -9oobn-question-what-is-the-belt-and-road-initiative.

Rumi, A. (2017). One Belt, One Road: China's new global strategy. Journal of Contemporary East Asia Studies, 5(2), 3-22. doi:10.108o/24761028.2016.11869o94.

Sanghi, A, \& Johnson, D. (2016). Deal or no deal. Strictly Business for China in Kenya. World Bank. Policy Research Working Paper, 7614.

Schindler, S., Kanai, J. M., \& Rwehumbiza, D. (2018). The 21st century rediscovery of regional planning in the global South. In A. Paasi, J. Harrison \& M. Jones (Eds.) Handbook on the Geographies of Regions and Territories (pp. 346-357). Edward Elgar.

Schindler, S., \& Kanai, J. M. (2019). Getting the territory right: infrastructure-led development and the re-emergence of spatial planning strategies. Regional Studies. doi :10.1080/00343404.2019.1661984.

Sun, X. (2015). Chinese FDI. A study of the impact of Chinese infrastructure investments in Kenya, Africa. Retrieved from https://academiccommons.columbia.edu/ doi/10.7916/D8CV4H9T.

Sun, Y. (2014) Africa in China's Foreign Policy. Brookings Institution Paper, April.

Taylor, I. (2011). China's Challenges: Africa. The Diplomat. Retrieved from: https://the diplomat.com/2011/o2/africa/.

Tiberghien, Y. (2017). Belt and Road Initiative aims to boost globalization. Retrieved from https://asia.nikkei.com/Politics/Belt-and-Road-Initiative-aims-to-boost -globalization.

Ubi, N. (2019). How Africa Can Benefit From China's Belt and Road Initiative. Financial Nigeria. July 2.

United Nations Economic and Social Council. (2009). The Transport Situation in Africa. United Nations Economic and Social Council.

Wang, Y. (2016). Offensive for defensive: The belt and road initiative and China's new grand strategy. The Pacific Review, 29(3), 455-463. doi:10.108o/09512748.2016 .1154690 .

Waweru, M. N. (2016). Impact of Infrastructure development on economic competitiveness in Kenya. M.A., Economics Thesis, University of Nairobi.

Wissenbach, U., \& Wang, Y. (2017, July 31). African politics meets Chinese engineers: The Chinese-built Standard Gauge Railway Project in Kenya and East Africa. Johns Hopkins University. Retrieved from https://statici.squarespace.com/ static/5652847de4bo33f56d2bdc29/t/594d739f3eoobed37482d4fe/1 498248096443/ SGR+v4.pdf.

World Bank. (2017) http://pubdocs.worldbank.org/en/9o8481507403754670/Annual -Report-2017-WBG.pdf. 
Xiang, B. (2019, April 13). Why Belt and Road Initiative is anything but debt trap.

Xinhua. https://www.focac.org/eng/zfgx_4/rwjl/t1657677.htm.

Yakunin, V. (2019). The Belt and Road Initiative as a new model for global inclusive development and solidarity. Retrieved from https://doc-research.org/2019/04/ the-belt-and-road-initiative-as-a-new-model-for-global-inclusive-development -and-solidarity/.

Yu, H. (2016). Motivation behind China's 'One Belt, One Road' Initiatives and Establishment of the Asian Infrastructure Investment Bank. Journal of Contemporary China, 26(105), 353-368. doi:10.108o/10670564.2016.1245894. 